\title{
The impact of macroeconomic variables on the evolution of the credit risk rate
}

\author{
Luminița Gabriela Istrate ${ }^{\mathrm{a} 1}$ and Bogdan Ștefan Ionescu ${ }^{\mathrm{a}}$
}

${ }^{\mathrm{a}}$ Bucharest University of Economic Studies, Romania

\begin{abstract}
The dynamics of the real economy is a major driver of the evolution of arrears at the level of the pool of loans granted to non-financial companies, completed by the financial pressure induced by the monetary conditions. Lending allows on the one hand providing resources for companies that need financing for investment projects, on the other hand, it supports the fund holders to place resources for obtaining profit. The role of the lending policy in the activity of commercial banks is very important, as it may influence both the cost of credits and the loan portfolio quality in the future. The purpose of this research is to find the macroeconomic variables that significantly influence credit risk and to develop a statistical model for predicting the doubtful and non-performing loans rate. Thus, it is envisaged the research of mechanisms by which the dynamics of the real economy and the money market conditions influence the evolution of the credit risk in different business sectors.
\end{abstract}

Keywords:credit risk, intermediate consumption, gross value added, foreign exchange rate, interest rate

JEL codes: E44, G21, O1

1 Corresponding author: Luminiţa Gabriela Istrate, Department of Accounting and Management Information Systems, Bucharest University of Economic Studies, 6, Romană Square, Bucharest, Romania, Telephone: (+40) 740627628, E-mail: istrate_luminita@yahoo.com 


\section{Introduction}

The sensitivity of non-performing (bad) loans dependent of the evolution of macroeconomic indicators varies from one sector to another, the economic sectors the most exposed to this process being those for which the banking system is financing an important part of the working capital, but also the demand for products / services provided.

According to Derelioğlu and Gurgen (2011) and Boss et al. (2009) the credit risk analysis aims to reduce future losses by estimating the potential risk and eliminating the newly proposed credit if the risk is greater than a defined tolerance value. In this respect, it is essential to identify the main factors determining this risk in order to manage it effectively.

The lending activity is not without risks and can generate non-performing loans, resulting from risk mismanagement. Non-performing loans occur when there are delays in the reimbursement and recovery of arrears, and the payment of assumed liabilities is not secured or is partially secured.

European supervisory authorities consider that a loan is non-performing when it has been more than 90 days without the debtor paying the agreed instalments. The level of non-performing loans should be at a level as low as possible due to the impact on bank profitability. This goal can be achieved only by a conservative lending policy practiced in line with the economic conditions and the financial environment and through an appropriate risk classification.

Of course, the origin of non-performing (bad) loans should not be sought exclusively in macroeconomic variables. The policies adopted by individual banks, particularly those relating to the increase in efficiency and the risk management, significantly influence the evolution of non-performing loans.

The study aims to outline a framework for highlighting the macroeconomic influences on the credit risk. The paper examines the macroeconomic conditions that have a significant impact on credit risk, proposing to familiarize the international public with the understanding of the aspects proposed in the analysis for the case of Romania. Thus, the paper analyzes the aggregate rate of the credit risk and the macroeconomic data of Romania for the period under review. As the study shows, the most significant influence on credit risk is the exchange rate, but the interest rate and the gross domestic product also have a significant impact. It should be stressed that an increase in the interest rate could be determined by a decision taken by the National Bank of Romania to increase the monetary policy interest rate in order to moderate the inflationary pressure. 
Taking into account the results of the statistical tests, the macroeconomic variables underlying the analysis play an important role in the financial stability of the monetary and banking system, the severe deterioration of one of them influencing the credit risk.

The paper proposes both a statistical and a qualitative study. The expected outcome of the qualitative analysis is to show the influence of the credit risk on the capital supporting a bank's activity. A loss from a bad credit is indirectly translated into a capital deficit through provisioning. Under these circumstances, capital increases have as their primary motivation the increase in credit risk due to non-performing loans and the recognition of loss. The study may be a starting point for research in the field of accounting since the credit risk rate has an indirect influence on the available capital, which implies that an increase in the level of non-performing loans leads to a higher level of credit risk specific provisions, thus reflecting a balance sheet expense and a loss in the profit and loss account and available capital. Thus, research results can be used to model the dynamics of some elements of the balance sheet of commercial companies through macroeconomic variables.

The research results have both practical applicability, as a basis for stress tests and for forecasting purposes, and also implications in economic policies, outlining the effects of credit risk through the macroeconomic environment. Further to the study in this article, a related analysis will look at identifying a causal relationship between macroeconomic variables and the capital of financial institutions.

The study is structured on several sections, ending with the main conclusions and future directions of analysis. After the introductory concepts, the paper presents, in the second section, the review of the specialized literature, and in section no. 3 describes the methodology of the research and presents the used data, detailing both the economic reasoning and the statistical records which led to the selection of explanatory variables. In the fourth section we synthesized the main aspects of the empirical research, this section dealing with data analysis and the presentation of the results obtained. The paper ends with the presentation of the conclusions and of the future directions of research within section no.5.

\section{Literature review}

Most empirical studies examine the influence of macroeconomic indicators on the non-performing loans. Mcwayizeni (2016) studied the impact of macroeconomic variables on non-performing loans, concluding that variables such as GDP, interest rate, exchange rate, public debt, sovereign debt, unemployment, the volume of imports, the volume of exports, have a significant influence on the dynamics of non-performing loans in emerging economies, but do not have a notable influence in the case of developed economies. 
Gaganis et al.(2010) show that there are four main criteria of banking stability: regulations, other attributes of the banking and financial sector, the institutional framework and the macroeconomic conditions. Thus, the GDP growth not only reduces the rate of non-performing loans, but it may delay the emergence of banking crises. Figlewski et al.(2012) state that the macroeconomic factors have a significant impact on the solvency of companies. These authors group the macroeconomic risk factors into three large classes:

1. Factors related to general macroeconomic conditions (unemployment rate, inflation, etc.)

2. Factors related to the direction in which the economy is evolving (a real GDP growth, changes in the consumer behavior, etc.)

3. Factors relating to conditions in the financial markets (interest rates, listing / delisting, etc.).

As far as the category of macroeconomic indicators with the greatest impact on credit risk is concerned, the views are divided. There are studies that claim that the dynamics of the real economy has the greatest impact on credit risk, while other authors have come to the conclusion that monetary factors have the greatest impact on the likelihood of non-reimbursement.

Thus, Makri and Papadatos (2016) suggest that the macroeconomic environment (public debt, unemployment, inflation) appears to be closely linked to the repayment of loans in arrears, and Makri et al. (2014) concluded that the macroeconomic variables have a significant influence on non-performing loans in the Euro area.

Following the same direction, Makri (2015) argues that in the analysis carried out in Greece, the probability of non-reimbursement at maturity of loans is influenced by unemployment, public debt, GDP, inflation, outstanding loan, capital adequacy, liquidity and profitability. Skala (2014) studied the factors influencing the credit policy of 356 commercial banks in Poland in the period from 2006 to 2012, highlighting the fact that the macroeconomic indicators have a strong impact on the non-performing credits.

If a bank can establish a link between the macroeconomic environment and systematic credit risk factors, this knowledge may help in assessing and managing the portfolio credit risk over time and may prove useful in dynamic credit risk management circumstances in which default scenarios can occur over a variety of economic conditions. Alessi et al. (2014) analyzed the setting up of provisions for loan impairment in the case of Italian commercial banks for the period from 2006 to 2012 , revealing that the provisions for impairment are positively associated with the non-performing loan rate and the loan/assets ratio. 
Some researchers (Diaz \& Olivero, 2011; Duican \& Pop, 2015; Fainstein \& Novikov, 2011; Festic et al., 2011; Fiori et al., 2007; Leitao, 2012; Mileris, 2012, 2014; Virolainen, 2004; Yeyati, 2010) have found relations between the macroeconomic factors and non-performing loans in the banking system. The amount of past non-performing loans interact with the macroeconomic changes and indicate that banks with more non-performing loans are more affected by the macro shocks. The results suggest that non-performing loans increase across banks as macroeconomic risks rise. However, the interaction terms and the macroeconomic factors are highly correlated, so it is difficult to disentangle the independent effects of each macroeconomic variable. Generally, banks with a higher exposure to macroeconomic risk are expected to experience larger non-performing loans. Istrate et al. (2016) consider that the number of debtors to credit is influenced by the interest rate, meaning that an increase in interest rates on the interbank market determines an increase in the probability of default at maturity of loans contracted, while the destination of loans contracted (equipment, treasury) does not significantly influence PD.

On the other hand, Castro (2013) determined based on a model of panel data that the credit risk is significantly influenced by the macroeconomic environment. Thus, the credit risk increases with the decrease in the GDP, the share price, but decreases with the increase in the unemployment rate or the real exchange rate appreciation. Berge and Boye (2007) state that as determinants of non-quality of lending and, implicitly, of bank loans, respectively of recording of NPLs by creditor banks, should be considered the very lack of quality or performance in the activities of the credit contract parties.

Most of banking crisis theories are based on changes in economic fundamentals as a natural consequence of business cycles, with credit growing procyclically. Credit grows rapidly when the economy is booming, as investors turn more optimistic about the future and lending standards deteriorate. When the economic growth slows down, this causes a collapse in crediting. The macroeconomic origins of banking crises lie in unsustainable macro policies and global financial conditions.

Louzis et al. (2012) examined the determinants of non-performing loans in the Greek banking sector, differentiated for each category of loans (consumer, corporate, mortgage loans). Assuming that both the macroeconomic indicators and the credit conditions affect the credit quality, the authors concluded that for all categories of loans the non-performing credit rate can be explained by the evolution of macroeconomic variables (GDP, unemployment, public debt, etc.) and the quality of management, mortgage credits being less sensitive to changes in macroeconomic indicators.

Derbali's study (2011) revealed a positive association between inflation and bank profitability. High inflation is generally associated with high interest rates, and 
therefore, high revenue. However, if inflation is not anticipated and banks are slow in adjusting interest rates, there is the possibility of a rapid growth of expenditure compared to banking revenue and therefore bank profitability can be negatively affected. Buch et al. (2014) analyzed the relationship between the macroeconomic variables and the credit policy in the US, investigating how banks under analysis perceive analyzed macroeconomic shocks, concluding that banks perceive shocks differently, depending on size, capitalization, liquidity.

The scientific literature analysis confirmed the importance of considering the systemic risk factors on credit risk in banks, because the loan portfolio quality is often strongly related to macroeconomic conditions. Pestova and Mamonov (2014) found that the most negative influence over the credit quality in Russia have had the macroeconomic conditions. The results obtained have highlighted the importance of macro-prudential regulations for improving the financial stability of the Russian banking system.

A preliminary conclusion drawn from most studies using the GDP growth rate as primary indicator of macroeconomic conditions and sustainability of the debt of a large group of borrowers indicates that a GDP rate growth translated by higher revenue determines a higher probability of repayment of loans by borrowers. Although the studies refer to the international environment, we believe that the macroeconomic factors influence the credit risk rate for Romania as well. However, the information available for the Romanian banking environment is not sufficiently well synthesized given that the National Bank of Romania does not disclose all prudential indicators.

\section{Considerations on research methodology}

The methodological solutions applied to identify a simplified functional form of macroeconomic models of credit risk measurement are based on multivariate regressions, estimated independently or simultaneously in equations. This research aims to assess the impact of the macroeconomic indicators under analysis on the deterioration of the loan portfolio. Work methodology is based on the analysis and interpretation of statistical results, the variables considered being analyzed using the multiple linear regression.

The empirical analysis is based on a set of annual data that allows the assessment of the process of repayment of loans contracted by non-financial corporations, with the aim of explaining the influence that independent variables have on the credit risk (the dependent variable).The empirical analysis is based on a set of data having an annual frequency, which allows the assessment of the process of reimbursement of loans contracted by non-financial companies. 
To capture the global economic conditions on the reimbursement behavior of companies in various economic sectors, the sensitivity of bank loan nonreimbursement rates to the dynamics of macroeconomic variables was studied distinctively in four distinct major business sectors: agriculture, construction, trade and services. Business sectors retained in the analysis are relevant to the national economy.

In order to carry out the research, the following question was formulated: Can the credit risk be predicted based on the evolution of macroeconomic variables? The conceptual model of the credit risk rate prediction system assumes that the functional relationship between the endogenous variable and the set of explanatory indicators is described by the logit function. The analysis covers annual frequency data from the period from 2009 to 2015 , available on the websites of the National Institute of Statistics and the National Bank of Romania.

For research purposes, we used:

- The „credit risk rate” dependent variable as it appears in the aggregated indicators for credit institutions on the website of the National Bank of Romania, expressed as a proportion of gross exposure on loans and interest classified under „doubtful” and „loss" in total loans and classified interest (excluding off balance sheet items) $-\mathrm{Y}$.

To quantify the credit risk, the National Bank of Romania used the credit risk rate to define the ratio between the gross exposure of non-bank loans classified as loss or doubtful and the total amount of loans classified as non-bank loans excluding off-balance sheet items. According to the prudential regulations of the National Bank of Romania, only loans for which minimum capital requirements for credit risk are categorized, at the individual level, according to the standard approach, the remainder of the portfolio being exempted from classification (for banks using the internal rating models). The credit risk rate is a more restrictive indicator of the loan portfolio quality than the non-performing loans share. If a loan is considered nonperforming if the debt service exceeds 90 days, the credit risk rate includes in addition the loans/interest with an outstanding debt service of less than 90 days, and the classification criteria also include the financial performance of the debtor and the principle of downgrading by contamination. ${ }^{2}$

$\circ$ The independent variables that were divided into two groups:

1. Variables of the real economy:

- gross value added $-\mathrm{X}_{1}$

- intermediate consumption $-\mathrm{X}_{2}$

- branch level production $-\mathrm{X}_{3}$

${ }^{2}$ According to the National Bank of Romania 
2. Monetary variables:

- EUR/RON exchange rate $-\mathrm{X}_{4}$

- ROBOR with a maturity of six months $-\mathrm{X}_{5}$

The analyzed data are shown in Table 1:

Table 1. Database with analyzed variables

\begin{tabular}{|c|c|c|c|c|c|c|}
\hline \multirow{4}{*}{ Year } & \multicolumn{3}{|c|}{ Real economy } & \multicolumn{2}{|c|}{ Monetary factors } & \multirow[b]{2}{*}{$\begin{array}{l}\text { Credit } \\
\text { risk } \\
\text { rate** }\end{array}$} \\
\hline & Production & $\begin{array}{l}\text { Intermediate } \\
\text { consumption }\end{array}$ & $\begin{array}{l}\text { Gross value } \\
\text { added }\end{array}$ & $\begin{array}{l}\text { EUR/RON } \\
\text { exchange } \\
\text { rate }\end{array}$ & ROBOR 6M & \\
\hline & (\% p.a.) & (\% p.a.) & (\% p.a.) & & (\% p.a.) & (\% p.a.) \\
\hline & $\mathbf{X}_{1}$ & $\mathbf{X}_{2}$ & $\mathbf{X}_{3}$ & $\mathbf{X}_{4}$ & $\mathbf{X}_{5}$ & $\mathbf{Y}$ \\
\hline \multicolumn{7}{|c|}{ Agriculture } \\
\hline 2009 & 0.857 & 0.867 & 0.847 & 3.337 & 0.078 & 0.040 \\
\hline 2010 & 1.196 & 1.187 & 1.207 & 3.682 & 0.131 & 0.065 \\
\hline 2011 & 0.969 & 0.971 & 0.967 & 4.237 & 0.117 & 0.152 \\
\hline 2012 & 0.888 & 0.836 & 0.945 & 4.209 & 0.072 & 0.208 \\
\hline 2013 & 1.084 & 1.037 & 1.139 & 4.237 & 0.065 & 0.232 \\
\hline 2014 & 0.775 & 0.811 & 0.739 & 4.456 & 0.057 & 0.299 \\
\hline 2015 & 1.276 & 1.223 & 1.337 & 4.419 & 0.046 & 0.321 \\
\hline \multicolumn{7}{|c|}{ Construction } \\
\hline 2009 & 1.341 & 1.343 & 1.339 & 3.337 & 0.078 & 0.040 \\
\hline 2010 & 1.260 & 1.259 & 1.262 & 3.682 & 0.131 & 0.065 \\
\hline 2011 & 0.911 & 0.921 & 0.901 & 4.237 & 0.117 & 0.152 \\
\hline 2012 & 1.123 & 1.265 & 0.955 & 4.209 & 0.072 & 0.208 \\
\hline 2013 & 0.903 & 0.957 & 0.809 & 4.237 & 0.065 & 0.232 \\
\hline 2014 & 0.974 & 0.966 & 0.989 & 4.456 & 0.057 & 0.299 \\
\hline 2015 & 0.956 & 0.913 & 1.044 & 4.419 & 0.046 & 0.321 \\
\hline \multicolumn{7}{|c|}{ Trade } \\
\hline 2009 & 1.158 & 1.161 & 1.157 & 3.337 & 0.078 & 0.040 \\
\hline 2010 & 1.142 & 1.177 & 1.119 & 3.682 & 0.131 & 0.065 \\
\hline 2011 & 0.863 & 0.856 & 0.868 & 4.237 & 0.117 & 0.152 \\
\hline 2012 & 1.176 & 1.266 & 1.115 & 4.209 & 0.072 & 0.208 \\
\hline 2013 & 1.062 & 1.036 & 1.128 & 4.237 & 0.065 & 0.232 \\
\hline 2014 & 1.258 & 1.135 & 1.647 & 4.456 & 0.057 & 0.299 \\
\hline 2015 & 0.884 & 1.001 & 0.673 & 4.419 & 0.046 & 0.321 \\
\hline
\end{tabular}

Vol. 17, No. 1 


\begin{tabular}{lllllll}
\hline \multicolumn{2}{l}{ Transport } \\
2009 & 1.056 & 1.058 & 1.054 & 3.337 & 0.078 & 0.040 \\
2010 & 1.060 & 1.071 & 1.052 & 3.682 & 0.131 & 0.065 \\
2011 & 0.956 & 0.999 & 0.920 & 4.237 & 0.117 & 0.152 \\
2012 & 0.921 & 0.954 & 0.893 & 4.209 & 0.072 & 0.208 \\
2013 & 0.984 & 1.068 & 0.890 & 4.237 & 0.065 & 0.232 \\
2014 & 1.034 & 0.970 & 1.131 & 4.456 & 0.057 & 0.299 \\
2015 & 1.072 & 1.097 & 1.041 & 4.419 & 0.046 & 0.321 \\
\hline
\end{tabular}

Source: http://www.bnr.ro, http://www.insse.ro and author's processing

\section{Data analysis based on empirical research}

In order to study the impact of the macroeconomic indicators evolution on the credit risk, using the panel data methodology, there were estimated some equations for determining the credit risk depending on the variables of real economy and monetary factors.

The period for which the analysis is conducted is 2009-2015, using series of annual frequency for the selected indicators. To facilitate interpretation of the coefficients obtained from the regression, the econometric analysis is performed on logarithmic series.

The independent variable coefficient indicates the percent by which the $\mathrm{Y}$ dependent variable changes when the $X_{j t}$ independent variables change by 1 percent. In the selection of specifications of the credit risk analysis models, we started from estimating the equation system. Given the complexity of the researched phenomenon and the objective limits on the coverage over time of the available information, the multivariate procedure of selection of the determinants aimed at building a reasonable number of models that encompass a diversity as high as possible of the independent variables.

In order to study the impact of independent variables on the credit risk, empirical correlations have been made between the dependent variable and the independent variables, the econometric analysis being performed by logarithmic series, for facilitating interpretation of obtained results.

The matrix of correlation of the analyzed variables (Table 2) shows that high values of credit risk are associated with exchange rate movements in all four industry sectors under analysis, as evidenced by the positive correlation between the rate of credit risk and the exchange rate.

On the other hand, the negative values of the correlation between the credit risk rate and production in the case of enterprises working in agriculture, respectively production, intermediate consumption, gross value added in the case of trade, 
construction and transport, show that the high values of the independent variables are associated with a low credit risk, while the low values of the independent variables are associated with a high credit risk.

Table 2. Matrix of correlation of the analyzed variables

\begin{tabular}{|c|c|c|c|c|c|c|}
\hline \multicolumn{7}{|l|}{ AGRICULTURE } \\
\hline & $\begin{array}{l}\text { Productio } \\
n\end{array}$ & $\begin{array}{l}\text { Intermediat } \\
e \\
\text { consumptio } \\
n\end{array}$ & $\begin{array}{l}\text { Gross } \\
\text { value } \\
\text { added }\end{array}$ & $\begin{array}{l}\text { Exchang } \\
\text { e rate }\end{array}$ & $\begin{array}{l}\text { ROBOR } \\
6 M\end{array}$ & $\begin{array}{l}\text { Credi } \\
t \text { risk } \\
\text { rate }\end{array}$ \\
\hline $\begin{array}{l}\text { Production } \\
\text { Intermediate } \\
\text { consumption }\end{array}$ & -0.258 & 1 & & & & \\
\hline Gross value added & -0.304 & 0.940 & 1 & & & \\
\hline Exchange rate & -0.825 & 0.025 & 0.095 & 1 & & \\
\hline ROBOR 6M & 0.030 & 0.103 & 0.011 & -0.482 & 1 & \\
\hline Credit risk rate & -0.751 & 0.016 & 0.113 & 0,957 & -0.635 & 1 \\
\hline \multicolumn{7}{|l|}{ TRADE } \\
\hline & $\begin{array}{l}\text { Productio } \\
n\end{array}$ & $\begin{array}{l}\text { Intermediat } \\
e \\
\text { consumptio } \\
n\end{array}$ & $\begin{array}{l}\text { Gross } \\
\text { value } \\
\text { added }\end{array}$ & $\begin{array}{l}\text { Exchang } \\
\text { e rate }\end{array}$ & $\begin{array}{l}\text { ROBOR } \\
6 M\end{array}$ & $\begin{array}{l}\text { Credi } \\
t \text { risk } \\
\text { rate }\end{array}$ \\
\hline $\begin{array}{l}\text { Production } \\
\text { Intermediate } \\
\text { consumption }\end{array}$ & 0.867 & 1 & & & & \\
\hline Gross value added & 0.891 & 0.552 & $\begin{array}{l}1 \\
-\end{array}$ & & & \\
\hline Exchange rate & -0.309 & -0.362 & 0.135 & 1 & & \\
\hline ROBOR 6M & -0.029 & -0.105 & $\begin{array}{r}0.059 \\
-\end{array}$ & -0.482 & 1 & \\
\hline Credit risk rate & -0.241 & -0.259 & 0.123 & 0.979 & -0.635 & 1 \\
\hline \multicolumn{7}{|l|}{ CONSTRUCTION } \\
\hline & $\begin{array}{l}\text { Productio } \\
n\end{array}$ & $\begin{array}{l}\text { Intermediat } \\
e \\
\text { consumptio } \\
n\end{array}$ & $\begin{array}{l}\text { Gross } \\
\text { value } \\
\text { added }\end{array}$ & $\begin{array}{l}\text { Exchang } \\
\text { e rate }\end{array}$ & $\begin{array}{l}\text { ROBOR } \\
6 M\end{array}$ & $\begin{array}{l}\text { Credi } \\
t \text { risk } \\
\text { rate }\end{array}$ \\
\hline $\begin{array}{l}\text { Production } \\
\text { Intermediate } \\
\text { consumption }\end{array}$ & 0.330 & 1 & & & & \\
\hline Gross value added & 0.865 & 0.209 & $\begin{array}{l}1 \\
-\end{array}$ & & & \\
\hline Exchange rate & -0.880 & -0.401 & 0.791 & 1 & & \\
\hline ROBOR 6M & 0.360 & 0.292 & $\begin{array}{l}0.157 \\
-\end{array}$ & -0.482 & 1 & \\
\hline Credit risk rate & -0.842 & -0.435 & 0.752 & 0.942 & -0.635 & 1 \\
\hline
\end{tabular}




\begin{tabular}{|c|c|c|c|c|c|c|}
\hline \multicolumn{7}{|l|}{ TRANSPORT } \\
\hline & $\begin{array}{l}\text { Productio } \\
n\end{array}$ & $\begin{array}{l}\text { Intermediat } \\
e \\
\text { consumptio } \\
n\end{array}$ & $\begin{array}{l}\text { Gross } \\
\text { value } \\
\text { added }\end{array}$ & $\begin{array}{l}\text { Exchang } \\
\text { e rate }\end{array}$ & $\begin{array}{l}\text { ROBOR } \\
6 M\end{array}$ & $\begin{array}{l}\text { Credi } \\
t \text { risk } \\
\text { rate }\end{array}$ \\
\hline $\begin{array}{l}\text { Production } \\
\text { Intermediate } \\
\text { consumption }\end{array}$ & 0.687 & 1 & & & & \\
\hline Gross value added & 0.834 & 0.175 & $\begin{array}{l}1 \\
-\end{array}$ & & & \\
\hline Exchange rate & -0.345 & -0.337 & $\begin{array}{l}0.211 \\
-\end{array}$ & 1 & & \\
\hline ROBOR 6M & -0.183 & -0.062 & $\begin{array}{l}0.177 \\
-\end{array}$ & -0.482 & 1 & \\
\hline Credit risk rate & -0.286 & -0.272 & 0.186 & 0,965 & -0.635 & 1 \\
\hline
\end{tabular}

In order to show the dependence between the selected variables in the chosen time frame, we estimated the regression model in Excel. The multiple correlation between variables shows that there is a strong link between the credit risk rate and the analyzed macroeconomic variables in all four business sectors (Table 3).

Table 3. Estimate of the regression model

\begin{tabular}{lllll}
\hline & Agriculture & Trade & Construction & Transport \\
\hline $\begin{array}{l}\text { SUMMARY OUTPUT } \\
\text { Regression Statistics }\end{array}$ & & & & \\
Multiple R & 0.999 & 0.998 & 0.999 & 0.999 \\
R Square & 0.999 & 0.996 & 0.999 & 0.999 \\
Adjusted R Square & 0.994 & 0.980 & 0.997 & 0.996 \\
Standard Error & 0.025 & 0.048 & 0.016 & 0.020 \\
years & 7 & 7 & 7 & 7 \\
\hline
\end{tabular}

Taking into account the results of the statistical tests, the macroeconomic variables underlying the analysis play an important role in the financial stability of the monetary and banking system, the severe deterioration of one of them influencing the credit risk rate. On the other hand, considering the specificity of the Romanian market, a raised $\mathrm{R}^{2}$ is not entirely unusual. Looking at the results, we see that the rate of credit risk is influenced in more than $99 \%$ of cases by the macro variables analyzed in all sectors under study (R Square $>99 \%$ ).

Of course, the results obtained are not surprising at all. As presented in Section no. 2, authors such as McwayizeniThwala(2016), Makri et al. (2014), Skala (2014), or Figlewski et al. (2012), concluded that macroeconomic indicators have a significant impact on credit risk. Studies on the impact of macroeconomic variables on the evolution of the credit risk rate are converging; the conclusion drawn from most studies is that macroeconomic variables have a significant influence on the 
evolution of the credit risk. Of these, the most significant impact on credit risk is the exchange rate, but also the variables such as interest rate and GDP.

The values of the statistical tests show that the obtained model meets the requirements of a good econometric performance. The dataset used was proved to be correct both from the point of view of the validation of the correlation coefficients and the compliance with the significance threshold (the probability associated with the $t$ test is lower than the most restrictive relevance level (1\%) and the probability associated with the $F$ test shows that at least one of the regression coefficients is significant from the statistical point of view).Next, we carried out the analysis of data series using the EViews software application to determine the correlation between the credit risk and the analyzed variables, the analysis result being presented in Table 4 .

Table 4. Research results in relation to the independent variables

\begin{tabular}{|c|c|c|c|c|c|c|c|c|}
\hline & \multicolumn{2}{|c|}{ Agriculture } & \multicolumn{2}{|l|}{ Trade } & \multicolumn{2}{|c|}{ Construction } & \multicolumn{2}{|c|}{ Transport } \\
\hline & Coeffici & tStd. Er & Coeffic & $\begin{array}{l}\text { Std. } \\
\text { Error }\end{array}$ & Coeffic & $\begin{array}{l}\text { Std. } \\
\text { Error }\end{array}$ & Coefficie & $\begin{array}{l}\text { Std. } \\
\text { t Error }\end{array}$ \\
\hline \multicolumn{9}{|l|}{ Real economy } \\
\hline Production & -0.041 & 0.029 & 5.065 & 13.990 & 0.648 & 0.256 & 82.307 & 34.214 \\
\hline $\begin{array}{l}\text { Intermediate } \\
\text { consumption }\end{array}$ & -0.625 & 0.447 & -2.484 & 7.941 & -0.176 & 0.102 & -48.469 & 20.233 \\
\hline VAB & 0.494 & 0.366 & -1.697 & 4.501 & -0.734 & 0.212 & -37.064 & 15.249 \\
\hline \multicolumn{9}{|c|}{ Monetary conditions } \\
\hline Exchange rate & 5.459 & 0.772 & 7.200 & 1.372 & 6.255 & 0.358 & 7.340 & 0.442 \\
\hline ROBOR 6M & 0.562 & 0.121 & 0.314 & 0.285 & 0.511 & 0.053 & 0.099 & 0.169 \\
\hline
\end{tabular}

The research results highlight the fact that the dynamics of the credit risk is influenced mainly by the evolution of monetary factors. Thus, an increase in the exchange rate determines an increase in the credit risk by $54.59 \%$ for enterprises operating in agriculture, $72 \%$ in trade, $62.55 \%$ in construction and $73.40 \%$ in the case of transport companies. Instead, for enterprises operating in the transport field, the credit risk rate is strongly influenced by the dynamics of the real economy, as demonstrated by the coefficients calculated for this business sector.

Unlike the results obtained in this research, Moinescu and Codirlaşu (2013) said in the study entitled "Sectoral dynamics of the bad loans rate: economic and monetary landmarks", that real economy dynamics is the main vector of the evolution of arrears at the level of the loan portfolio granted to non-financial corporations, the monetary pressure induced by monetary conditions being a secondary element, with the exception of the construction sector.

On the other hand, Trenca and Benyovszki (2008) using a credit risk model to determine the influence of macroeconomic factors (GDP growth rate, real interest 
rate, exchange rate) on default rates of the Romanian corporate sector (industry, services, construction, agriculture) over the period 2002-2007, concluded that the interest rate has a major impact on credit risk.

Both the dependent variable and the independent variables are expressed in natural logarithms, indicating the percent by which the dependent variable changes to a $1 \%$ increase in the independent variables. Thus, a $1 \%$ increase in production shall cause a decrease in the credit risk by $4.09 \%$ for enterprises operating in agriculture, while in the case of enterprises operating in the other sectors, the increase of production shall not determine the decrease of the credit risk rate. At the same time, the increase in the intermediate consumption determines the decrease in the credit risk rate in all business sectors, while the increase in the gross value added reduces the credit risk rate for enterprises in trade, construction and transport sector, but not for those in the agricultural sector. As per the monetary factors, it can be noticed that the credit risk increases with the increase in the exchange rate and the interest rate in all analyzed sectors.

\section{Conclusions and directions for future research}

The econometric results suggest that the real economy and the monetary factors influence the evolution of the credit risk rate in all four analyzed industry sectors. As future lines of research, we suggest introducing more macro variables in the analysis, variables that influence the probability of default.

The credit risk is one of the most important risks that the banks are facing, which is why in recent years focus was set on the adoption of banking business patterns, in order to enable financial institutions to develop an effective framework for risk assessment, but without putting profitability at risk.

The development and application of techniques for managing the credit risk is an old concern that has evolved from techniques such as exposure assessment, to limit excessive focus on a single borrower, business sector or industry branch, to modern techniques such as transactions with swaps and options, tailored to this risk. Banks should identify and assess the degree of risk that accompanies each credit application, and where the risk is high it will be reflected in the credit conditions (high interest rate). The degree of risk associated with a firm or a credit granted for that company is determined both by internal factors and external factors among which the company operates (macroeconomic factors).The global economy evolution, but also the current developments in the Romanian economy commit to a policy of careful risk measurement to achieve acceptable returns in the future, given the influence that the bank may suffer from competing external factors. 


\section{References}

Alessi, M., Di Colli, S. \& Lopez, J.S. (2014) "Loan loss provisioning and relationship banking in Italy: Practices and empirical evidence", Journal of Entrepreneurial and Organizational Diversity, vol. 3, no. 1: 111-129

Berge, T.O. \& Boye, K.G. (2007) "An analysis of bank's problem loans", Norges BankEconomic Bulletin, vol.78: 65-76

Boss, M., Fenz, G., Pann, J., Puhr, C. Schneider, M. \& Ubl E. (2009) "Modeling credit risk through the Austrian business cycle: An update of the OeNB Model", OeNB Financial Stability Report, vol. 17: 85-101

Buch, C., Eickmeier, S. \& Prieto, E. (2014) "Macroeconomic factors and micro level bank behavior", Journal of Money, Credit and Banking, vol. 46, no. 4: 715-751

Castro, V. (2013) "Macroeconomic determinants of the credit risk in the banking system: The case of the GIPSI", Economic Modelling, vol. 31: 672 -683

Derbali, A. (2011) "Determinants of banking profitability before and during the financial crisis of 2007: The case of Tunisian banks", Interdisciplinary Journal of Contemporary Research in Business, vol.3: 1256-1269

Derelioglu, G. \& Gurgen, F. (2011) "Knowledge discovery using neural approach for SME's credit risk analysis problem in Turkey", Expert Systems with Applications, no.38: 9313-9318

Diaz, R. A. \& Olivero, M. P. (2011) "The cyclicality of price-cost margins in banking: an empirical analysis of its determinants", Economic Inquiry, vol. 49 , no. $1: 26-46$

Duican, E.R.\& Pop, A. (2015) "The implications of credit activity on economic growth in Romania", Procedia Economics and Finance, no.30: 195 - 201

Fainstein, G. \& Novikov, I. (2011) "The comparative analysis of credit risk determinants in the banking sector of the Baltic States", Review of Economics \& Finance, no. 3: 20-45

Festic, M., Kavkler, A. \& Repina, S. (2011) "The macroeconomic sources of systemic risk in the banking sectors of five new EU member states", Journal of Banking \& Finance, no. 35: 310-322

Figlewski, S., Frydman, H. \& Liang, W. (2012) "Modelling the effect of macroeconomic factors on corporate default and credit rating transitions", International Review of Economics and Finance, vol. 21: 87-105

Fiori, R., Foglia A. \& Iannotti S. (2007) "Estimating macroeconomic credit risk and sectoral default rate correlations for the italian economy", Working Paper, Bank of Italy

Gaganis, C., Pasiouras, F., Doumpos, M. \& Zopounidis, C. (2010) "Modelling banking sector stability with multicriteria approaches", Optimization Letters, vol. 4: 543-558 
Istrate, L.G., Ionescu, B.Ș. \& Haralambie, M. (2016) "Aspects of the impact of interest rate development on the probability of default", Audit Financiar, vol. 14, no. 142: 1149-1156

Leitao, N.C. (2012) "Bank, credit, and economic growth. A dynamic panel analysis", The Economic Research Guardian, vol. 2(2): 256-267

Louzis, D., Vouldis, A. \& Metaxas, V. (2012) "Macroeconomic and bank-specific determinants of non-performing loans in Greece: A comparative study of mortgage, business and consumer loan portfolios", Journal of Banking \& Finance, vol. 36, no. 4: 1012-1027

Makri, V., Tsagkanos, A. \& Bellas, A. (2014) "Determinants of non-performing loans: The case of eurozone",Panoeconomicus, vol. 61, no.2: 193-206

Makri, V. (2015) "What triggers loan losses? An empirical investigation of Greek financial sector", SPOUDAI Journal of Economics and Business, vol.65, no. 2: $119-143$

Makri,V. \& Papadatos, K. (2016) "Determinants of loan quality: Lessons from Greek cooperative banks", Review of Economic \& Business Studies, vol. 9, no.1: $115-140$

Mcwayizeni Thwala, C. (2016) "The sensitivity of bank credit risk indicators to macroeconomic variables", A dissertation submitted to the Faculty of Commerce, Law and Management University of the Witwatersrand Business School, Johannesburg

Mileris, R. (2012) "The effects of macroeconomic conditions on loan portofolio credit risk and banking system interest income", Ekonomika, vol. 91, no. 3: $85-100$

Mileris, R. (2014) "Macroeconomic determinants of loan portfolio credit risk in banks", Inzinerine Ekonomika-Engineering Economics, vol. 23, no. 5: 496-504

Moinescu, B. \& Codirlașu, A., (2013) "Lending, economic growth and nonperforming loans: empirical evidences from the new EU member states", Working Paper

Skała, D. (2014) "Credit policy in small polish banks - Is there room for income smoothing?", Collegium of Economic Analysis Annals, Warsaw School of Economics, no.34: 183-196

Trenca, I. \& Benyovszki, A. (2008) "Credit risk, a macroeconomic model application for Romania", Finance - Challenges of the Future, no. 7: $118-126$

Virolainen, K. (2004) "Macro stress testing with a macroeconomic credit risk model for Finland", Bank of Finland, Discussion Papers No.18

Yeyati, E. L., Peria, M. S. M.\& Schmukler, S. L. (2010) "Depositor behavior under macroeconomic risk: evidence from bank runs in emerging economies", Journal of Money, Credit and Banking, vol. 42, no 4: 585-614 